\title{
EFFECT OF PHYSICO-MORPHIC CHARACTERS AND ENVIRONMENTAL FACTORS ON INFESTATION OF THRIPS (THRIPS TABACI) ON FIVE ONION CULTIVARS
}

\author{
Ajmal Hussain ${ }^{1}$, Humayun Javed ${ }^{1}$, Khadija Javed ${ }^{2}$, Muhammad Hanif ${ }^{3}$ \\ ${ }^{1}$ Department of Entomology, Pir Mehr Ali Shah Arid Agriculture University, Rawalpindi, Pakistan. \\ ${ }^{2}$ The State Key Laboratory for Bio-Pesticides Engineering of Plant Disease Biocontrol and Insect Pests, Institute of Plant \\ Protection, Chinese Academy of Agricultural Science, No. 12 Zhong-Guan-Cun South Street, Beijing 100081, China. \\ ${ }_{3}^{3}$ Department of Mathematics and Statistics, Pir Mehr Ali Shah Arid Agriculture University, Rawalpindi, Pakistan.
}

A R T I C L E I N F O

\begin{tabular}{l} 
Article history \\
Received: $31^{\text {st }}$ January, 2020 \\
Revised: $19^{\text {th }}$ March, 2020 \\
Accepted: $22^{\text {nd }}$ March, 2020 \\
\hline
\end{tabular}

Keywords

Physico-morphic characters

Environmental factors

Allium cepa

Red Orb

Marvi
A B S T R A C T

\begin{abstract}
Resistance to plants is frequently associated with physical, morphological, physiological, biochemical, molecular and genetic characteristics of the plants. As very little information is available on the effects of physico-morphic characteristics and environmental factors on thrips (Thrips tabaci) infestation, therefore, in the present study such effects were evaluated on the infestation of thrips on five onion cultivars. Maximum number of adults and infestation of thrips was recorded on Marvi followed by Golden Orb while the adults and infestation was the minimum on Red Orb. Significant variations were observed in plant heights and girths among five onion varieties after 40, 70 and 100 days. Similarly, maximum yield was observed in case of Red Orb followed by F1 Mustang while the minimum yield was obtained with cultivar Marvi. The low temperature, high temperature and average temperature showed significant and positive correlations among all the cultivars. However, the average relative humidity showed negative and non-significant correlation for all the varieties. The correlation between physico-morphic characteristics and adult population was found significant for plant girth after 40 days while the correlations were non-significant for all the other factors. It is concluded from the present studies that Red Orb is comparatively resistant cultivar harboring the minimum thrips population. The highest yield was also recorded in case of Red Orb as compared to other tested cultivars and recommended for cultivation to enhance economic returns of farmers.
\end{abstract}

Corresponding Author: Humayun Javed

Email: hjhumayun@gmail.com

(C) 2020 EScience Press. All rights reserved.

\section{INTRODUCTION}

Onion (Allium cepa $L$.) belongs to the family Alliaceae which is also known as Amaryllidaceae and is a biennial herbaceous crop (Malik et al., 2010). Onion is known as a major horticultural cash crop in Pakistan (Hassan and Malik, 2002). Onion contains high amount of phosphorus, calcium and carbohydrates and is a rich source of energy. It is pungent because of sulphuric compound and is also used as appetizer (Anonymous, 2012).

In India, onion is cultivated on large area for the consumption of domestic purpose as well as for export (Brewster, 1994). Onion is seriously attacked by 
different insect pests including thrips, maggots, head borer and cutworm etc. which are main yield reducing factors. Among these, Thrips tabaci, is the major pest of onion (Lorbeer et al., 2002; Malik et al., 2010). T. tabaci causes damage to onion directly by feeding and indirectly by transmitting viruses (Whitfield et al., 2005). As compared to other insect pests of onion, $T$. tabaci is the most serious pest in tropical areas (Duchovskiene, 2006; Richter et al., 1999).

The number of thrips increases from bulb initiation and attacks all stages of crop growth (Ibrahim and Adesiyun, 2009). As compared to adult, nymph does more damage usually in peculiar feeding behavior in fruit as well as in flower of onion (Kawai, 1988). During the last two decades, it has become a globally recognized pest of onion (Diaz-Montano et al., 2011). Onion thrips is known as the most economically important pest of onion all over the world (Trdan et al., 2005). Thrips causes damage to onion crop and yield reduction may reach up to $59 \%$ (Waiganjo et al., 2008). In many cases, the yields of onion reduce up to 40-60\% (Fournier et al., 1995; Khan et al., 2015). They also reported $43 \%$ yield loss in yellow onions and recorded 149-172 adults per leaf. It has wide host range and can transfer from one crop to others depending upon the environmental conditions (Shelton et al., 1987). Al-Faisali (1981) reported that thrips population in onion fields may fluctuate depending on environmental conditions, plant age, time and amount of rainfall and temperature. The highest density in onion field may occur during the months of March and April.

To minimize damage, cultivars resistant to the insect pests must be used (Sinha et al., 1993). The onion varieties are regarded as resistant or susceptible to onion thrips on the basis of leaf color while the length of 'days to maturity' is not the best way to indicate resistant and susceptibility of onion crop (Diaz-Montano et al., 2010). Various studies on onion resistance against T. tabaci have been reported which has been found to be associated with onion bulb color (Verma, 1996). There are also reports that thrips has developed resistance to commonly used of insecticides (Martin et al., 2003).

Insect pests are mainly controlled by synthetic pesticides which have adverse side effects and resulted in resurgence of secondary pests, environmental pollution, elimination of beneficial fauna, pest resistance to specific insecticides and various human health problems. The overreliance on pesticides can be avoided by using alternative approaches. The use of resistant cultivars can be one of the feasible options to replace harmful pesticides. The resistant cultivars can be economically feasible, environmentally benign, and secure and can minimize yield losses.

Resistance to plants is frequently associated with physical, morphological, physiological, biochemical, molecular and genetic characteristics of the plants. As very little information is available on the effects of physico-morphic characteristics and environmental factors on thrips infestation, therefore, in the present study such effects were evaluated on the infestation of thrips on five onion cultivars.

\section{MATERIALS AND METHODS}

The study was carried out at the University Research Farm Koont of Pir Mehr Ali Shah Arid Agriculture University Rawalpindi, Pakistan. Randomized Complete Block Design was followed to evaluate five onion cultivars viz. Marvi, Golden Orb, F1 Mustang, White Pearl and Red Orb for different parameters. The nursery of these varieties was raised at the greenhouse of Plant Breeding and Genetics, Pir Mehr Ali Shah Arid Agriculture University Rawalpindi. Seedlings were transplanted 60 days after emergence at University Research Farm Koont in the micro plots measuring $20 \times 25 \mathrm{~m}$. A distance of 10 $\mathrm{cm}$ and $15 \mathrm{~cm}$ was maintained for plants and rows respectively. Each variety was replicated three times. Irrigation was done at 7-10 days interval. Thrips populations was observed from five randomly selected plants of each replication of each variety on weekly basis. Heights and girths of five randomly selected plants from each replication of each treatment were measured with the help of measuring tape and Vernier caliper at an interval of 40, 70 and 100 days after transplanting of onion. The yield of each plot of each variety was recorded at the harvesting of onion. To study correlation between environmental factors and adult population of thrips on five onion cultivars, weather data were collected from Meteorological Research Station Rawalpindi. The adult population was correlated with different environmental factors. Data related to population of T. tabaci on different cultivars of onion and physico-morphic characters of various cultivars were subjected to Analysis of Variance and means were compared with Duncan's Multiple Range Test at $5 \%$ level of probability and for simple correlation.

\section{RESULTS AND DISCUSSION}

The thrips infestation on five onion cultivars is given in Table 1. Maximum number of adults and infestation was 
recorded on Marvi followed by Golden Orb while the adults and infestation was the minimum on Red Orb. Significant variations were observed in plant heights and girths among five onion varieties after 40, 70 and 100 days (Table 2 and 3). Similarly, maximum yield was observed in case of Red Orb followed by F1 Mustang while the minimum yield was obtained with cultivar Marvi (Table 4).

Table 1: Number of adults of Thrips tabaci per leaf and \% leaf infestation on five onion cultivars.

\begin{tabular}{lcc}
\hline Cultivars & No. of adults per leaf & \% leaf infestation \\
\hline Marvi & $3.4 \mathrm{a}$ & $43.04 \mathrm{a}$ \\
Golden Orb & $3.0 \mathrm{a}$ & $34.03 \mathrm{~b}$ \\
F1 Mustang & $2.4 \mathrm{~b}$ & $32.88 \mathrm{~b}$ \\
White pearl & $2.3 \mathrm{~b}$ & $32.27 \mathrm{~b}$ \\
Red Orb & $1.6 \mathrm{c}$ & $22.58 \mathrm{c}$
\end{tabular}

LSD value $=0.79$, Means sharing the similar letters are not significantly different by the DMR Test at $\mathrm{P}=0.05$.

Table 2: Mean plant height $(\mathrm{cm})$ of onion cultivars after three time intervals.

\begin{tabular}{lccc}
\hline Cultivars & \multicolumn{3}{c}{ Plant height after } \\
\cline { 2 - 4 } & 40 days & 70 days & 100 days \\
\hline Red Orb & $19.94 \mathrm{a}$ & $25.26 \mathrm{a}$ & $33.76 \mathrm{a}$ \\
F1 Mustang & $17.46 \mathrm{~b}$ & $23.31 \mathrm{~b}$ & $26.49 \mathrm{~b}$ \\
Golden Orb & $15.70 \mathrm{c}$ & $20.51 \mathrm{c}$ & $23.58 \mathrm{c}$ \\
White pearl & $15.02 \mathrm{c}$ & $20.05 \mathrm{c}$ & $22.10 \mathrm{~d}$ \\
Marvi & $14.95 \mathrm{c}$ & $18.13 \mathrm{~d}$ & $21.45 \mathrm{~d}$ \\
\hline
\end{tabular}

$\mathrm{LSD}=0.79$, Means sharing the similar letters are not significantly different by the DMR Test at $\mathrm{P}=0.05$.

Table 3: Mean plant girth (mm) of onion cultivars after three time intervals.

\begin{tabular}{lccc}
\hline Cultivars & \multicolumn{3}{c}{ Plant girth $(\mathrm{mm})$ after } \\
\cline { 2 - 4 } & 40 days & 70 days & 100 days \\
\hline Red Orb & $9.84 \mathrm{a}$ & $23.61 \mathrm{a}$ & $29.50 \mathrm{a}$ \\
F1 Mustang & $9.78 \mathrm{ab}$ & $23.1 \mathrm{~b}$ & $26.32 \mathrm{~b}$ \\
White pearl & $9.52 \mathrm{abc}$ & $20.81 \mathrm{~b}$ & $24.33 \mathrm{c}$ \\
Golden Orb & $9.21 \mathrm{bc}$ & $20.56 \mathrm{~b}$ & $24.21 \mathrm{c}$ \\
Marvi & $9.02 \mathrm{c}$ & $20.02 \mathrm{~b}$ & $23.40 \mathrm{c}$
\end{tabular}

$\mathrm{LSD}=0.59$, Means sharing the similar letters are not significantly different by the DMR Test at $\mathrm{P}=0.05$.

Table 4: Mean yield in gram per five plants of different onion cultivars.

\begin{tabular}{lc}
\hline Cultivars & Means \\
\hline Red Orb & $155.5 \mathrm{a}$ \\
F1 Mustang & $129.6 \mathrm{~b}$ \\
White pearl & $123.4 \mathrm{c}$ \\
Golden Orb & $115.5 \mathrm{c}$ \\
Marvi & $100.3 \mathrm{~d}$ \\
\hline
\end{tabular}

LSD value $=5.85$, Means sharing the similar letters are not significantly different by the DMR Test at $\mathrm{P}=0.05$.

The data related to correlation among weather factors and T. tabaci adults' population on various onion cultivars is given in table 5 . The low temperature, high temperature and average temperature showed 
significant and positive correlations among all the cultivars. However, the average relative humidity showed negative and non-significant correlation for all the varieties. The correlation between physico-morphic characteristics and adult population was found significant for plant girth after 40 days while the correlations were non-significant for all the other factors (Table 6).

Table 5: Correlation of adult population of onion thrips on different onion cultivars with different weather factors.

\begin{tabular}{llllll}
\hline Cultivar & Minimum & Maximum & Average & Average & Average rainfall \\
& Temperature & Temperature & Temperature & R.H\% & \\
\hline F1Mustang & $0.78^{* *}$ & $0.73^{*}$ & $0.76^{* *}$ & $-0.53 \mathrm{~ns}$ & $-0.06^{\mathrm{ns}}$ \\
Marvi & $0.79^{* *}$ & $0.83^{* *}$ & $0.82^{* *}$ & $-0.73 \mathrm{~ns}$ & $-0.04^{\mathrm{ns}}$ \\
White pearl & $0.80^{* *}$ & $0.82^{* *}$ & $0.82^{* *}$ & $-0.66^{*}$ & $0.03^{\mathrm{ns}}$ \\
Red Orb & $0.88^{* * *}$ & $0.91^{* * *}$ & $0.90^{* * *}$ & $-0.62 \mathrm{~ns}$ & $0.07^{\mathrm{ns}}$ \\
Golden Orb & $0.82^{* *}$ & $0.83^{* *}$ & $0.83^{* *}$ & $-0.54 \mathrm{~ns}$ & $0.28^{\mathrm{ns}}$ \\
\hline
\end{tabular}

${ }^{*}=$ Significant, ${ }^{* *}$ and ${ }^{* * *}=$ Highly Significant, ns= Non significantly at 0.05

Table 6: Correlation of physico-morphic characteristics of different onion cultivars with adult population of onion thrips.

\begin{tabular}{lc}
\hline Physico-morphic character & Correlation with adult population \\
\hline Height After 40 days & $-0.816^{\mathrm{ns}}$ \\
Height After 70 days & $-0.625^{\mathrm{ns}}$ \\
Height After 100 days & $-0.77^{\mathrm{ns}}$ \\
Girth of plant after 40 days & $-0.96^{* *}$ \\
Girth of plant after 70 days & $-0.677^{\mathrm{ns}}$ \\
Girth of plant after 100 days & $-0.87^{\mathrm{ns}}$ \\
\hline
\end{tabular}

Many researchers have reported number of adults and infestation of thrips on different onion cultivars. The present findings are to some extent similar to those observed by Aziz et al. (2012), Mastoi et al. (2013), Akhter et al. (2014), Afzal et al. (2015) and Afzal et al. (2015) on various crops. Earlier many researchers have studied variations in various physico-morphic characters of different cultivars of different vegetables (Farooq et al., 2002; Makhadmeh and Khalil, 2004; Shah and Khan, 2015; Singh et al., 2015).

\section{CONCLUSION}

It is concluded from the present studies that Red Orb was found comparatively resistant cultivar harboring the minimum thrips population. The highest yield was also recorded on Red Orb, as compared to other tested cultivars and recommended for cultivation to enhance economic returns of farmers.

\section{CONFLICT OF INTEREST}

The authors declare no conflict of interest.

\section{AUTHORS' CONTRIBUTION}

$\mathrm{AH}, \mathrm{HJ}$ and $\mathrm{KJ}$ designed the study, $\mathrm{AH}$ conducted the experiments and collected data, $\mathrm{MH}$ analyzed the data,
HJ supervised the work, $\mathrm{AH}$ and KJ wrote the manuscript and all the authors edited and approved the final manuscript.

\section{REFERENCES}

Afzal, M., Mukhtar, K.M., Tahir, H.M., Ibrar-ul-Haq., Babar, M.H., Sherawat, S.M., 2015. Screening of different okra genotypes against fruit borer (Earias spp.) (Lepidoptera: Noctuidae) on okra crop. Pakistan Journal of Zoology 47, 1631-1635.

Akhter, M., Jabeen, F., Sultana, S., Sultana, T., Hussain, D., Ali, A., 2014. Selection of different okra genotypes against Earias spp. (Lepidoptera: Noctuidae) Journal of Entomology and Zoology Studies 2, 138141.

Al-Faisali, A.M., 1981. Ecological studies on onion thrips, Thrips tabaci Lindeman (Thripidae: Thysanoptera) in Iraq. College of Science, 85.

Anonymous, 2012. Onion exporter from Pakisatan Available online with updates at www.awanfruits.com.pk.

Aziz, M.A., Hasan, M., Ali, A., Iqbal, A., 2012. Comparative efficacy of different strategies for management of 
spotted bollworms, Earias spp. on okra, Abelmoschus esculentus (L.) Moench. Pakistan Journal of Zoology 44, 1203-1208.

Brewster, J.L., 1994. Onion and other vegetable allium. CABI International Publisher.

Diaz-Montano, J., Fuchs, M., Nault, B.A., Fail, J., Shelton, A.M., 2011. Onion cultivars thrips, Thrips tabaci (Thysanoptera: Thripidae ) A global pest of increasing concern in onion. Journal of Economic Entomology 104, 1-13.

Diaz-Montano, J., Fuchs, M., Nault, B.A., Shelton, A.M., 2010. Evaluation of onion cultivars for resistance to onion thrips (Thysanoptera: Thripidae ) and Iris Yellow spot virus. Journal of Economic Entomology 103, 905-937.

Duchovskiene, L., 2006. The abundance and population dynamics of union thrips (Thrips tabaci Lind.) in leek under field conditionds. Agronomy Research 4, 163-166.

Farooq, A.K., Jalal-Ud-Din., Ghaffoor, A., Khan, K.W., 2002. Evaluation of different varieties of 'okra' (Abelmoscus esculentus L.) under the agroclimatic conditions of Dera Ismail Khan. Asian Journal of Plant Sciences 1, 663-664.

Fournier, F., Boiven, G., Stewart, R.K., 1995. Effect of Thrips tabaci (Thysanoptera: Thripidae ) on yellow onion yields and economic threshold for its management. Journal of Economic Entomology 88, 1401-1407.

Hassan, S., Malik, M.F., 2002. Weeds management in broadcasted onion (Allium cepa). Asian Journal of Plant Sciences 1, 28-30.

Ibrahim, N.D., Adesiyun, A.A., 2009. Effect of age and height of onion (Allium cepa L.) plant on infestation thrips T. tabaci Lind in Sokoto Nigeria. African Journal of Agricultural Research 4, 76-84.

Kawai, A., 1988. Studies on population ecology of Thrips palmi karnay 16 Distribution among leaves, flowers and fruits on aubergine and sweet pepper. Japanese Journal of applied Entomology and Zoology 32, 291-296.

Khan, A.B., Panhwar, W.A., Mehmood, S.A., Gilal, A.A., Ahmad, S., Halimullah., 2015. Population of Thrips tabaci Lindeman, 1889 in onion crop from district Mansehra, Khyber Pakhtunkhwa, Pakistan. Journal of Entomology and Zoology Studies 5, 502-505.

Lorbeer, J.W., Kahur, T.P., Hoffmann, M.P., 2002. Monitoring and forecasting for disease and insect attack in onion and Allium crops within IPM strategies in Rabinowitch. Allium Crop Science 6, 293-309.

Makhadmeh, I.M., Khalil, I.E., 2004. Geometric characteristics and chemical composition of okra (Abelmoschus esculentus L.) grown under semiarid conditions. International Journal of Food Properties 7, 83-90.

Malik, M.F., Rashid, M., Iqbal, J., Ahmad, A., 2010. Resistance determination against thrips of promising onion varieties in the agro-ecosystem of Balochistan. Punjab University Journal of Zoology 25, 1-11.

Martin, N.A., Workman, P.J., Butler, R.C., 2003. Insecticide resistance in onion thrips (Thrips tabaci) (Thysanoptera: Thripidae). New Zealand Journal of Crop and Horticultural Science 31, 99-106.

Mastoi, A.H., Memon, S.A., Haq, W., 2013. Varietal resistance of okra against whitefly (Bemisia tabaci) and fruit borer (Earias spp). Scholarly Journal of Agricultural Science 3, 78-82.

Richter, E., Hommes, M., Krauthausen, J.H., 1999. Investigation on the supervised control of $T$. tabaci in leek and onion crops. IQBC/WPRS Bulletin 22, 61-72.

Shah, R.A., Khan, I.A., 2015. Evaluation of onion cultivars against onion thrips, Thrips tabaci Lind infection on onion crop. Journal of Entomology and Zoology Studies 32, 121-123.

Shelton, A.M., Nyrop, J.P., North, R.C., Petzoldt, C., Foster, R., 1987. Development and use of a dynamic sequential sampling program for onion thrips, Thrips tabaci (Thysanoptera: Thripidae) on onion. Journal of Entomology 80, 1051-1056.

Singh, B., Chaubey, T., Upadhyay, D.K., Aastik, J.H.A., Pandey, S.D., Sanwal, S.K., 2015. Indian Council of Agricultural Research, New Delhi, India. Indian Journal of Agricultural Sciences 85, 1192-1200.

Sinha, A.K., Sinha, R.B.P., Ajag, K., Kumar, A., 1993. Reaction of onion cultivars to thrips (Thrips tabaci). Journal of Applied Biology 3, 104-105.

Trdan, S., Vali, N., Zezlina, I., Bergant, K., Zindar, D., 2005. Light blue sticky boards for mass trapping of onion thrips, Thrips tabaci Lind (Thysanoptera: Thripidae) in onion crop. Journal of Plant Diseases and Protection 12, 173-180.

Verma, S.K., 1996. Studies on the host preference of the onion thrips, Thrips tabaci Lind to the varieties of 
onion. Indian Jouranl of Entomology 28, 396-398.

Waiganjo, M.M., Mueke, J.M., Gitonga, L.M., 2008. Susceptible onion growth stages for selective and economic protection from onion thrips infestation.
Acta Horticulturae 767, 193-200.

Whitfield, A.E., Ullman, D.E., German, T.L., 2005. Tospovirus-thrips interaction. Annual Review of Phytopathology 43, 459-489. 